\title{
Regional Air Quality of the Nigeria's Niger Delta
}

\author{
Precious N. Ede, David O. Edokpa* \\ Institute of Geosciences and Space Technology, Rivers State University of Science and Technology, \\ Port Harcourt, Nigeria \\ Email: onodavee@yahoo.com
}

Received 8 February 2015; accepted 25 February 2015; published 2 March 2015

Copyright (C) 2015 by authors and Scientific Research Publishing Inc.

This work is licensed under the Creative Commons Attribution International License (CC BY). http://creativecommons.org/licenses/by/4.0/

(c) (i) Open Access

\section{Abstract}

There is no systematic attempt to evaluate the air quality of any settlement in the Niger Delta region over a long period. Records of air quality data for this study were generated through secondary sources from impact assessment of facilities aimed at implementing air quality regulations on the environment. Suspended particulate matter in the region's atmosphere ranged from 40 $\mu \mathrm{g} / \mathrm{m}^{3}$ in Brass to $98 \mu \mathrm{g} / \mathrm{m}^{3}$ in Port Harcourt. Carbon monoxide concentrations were highest in Mbiama $\left(191 \mu \mathrm{g} / \mathrm{m}^{3}\right)$. Nitrogen dioxide concentration was highest in Bonny $\left(187 \mu \mathrm{g} / \mathrm{m}^{3}\right)$, and sulphur dioxide concentrations ranged from $19 \mu \mathrm{g} / \mathrm{m}^{3}$ in Ukwugba to $90 \mu \mathrm{g} / \mathrm{m}^{3}$ in Port Harcourt. Total hydrocarbon ranged from $78 \mu \mathrm{g} / \mathrm{m}^{3}$ in Odukpani to $192 \mu \mathrm{g} / \mathrm{m}^{3}$ in Nchia. Carbon dioxide ranged from $400 \mathrm{ppm}$ in Buguma to $450 \mathrm{ppm}$ in Port Harcourt. The most abundant of the Vocs is benzene and toluene. Ethylene was detected only in one station at concentration of $0.1 \mu \mathrm{g} / \mathrm{m}^{3}$ which was negligible. The most abundant of the metals was zinc, which was present at above $2 \mu \mathrm{g} / \mathrm{m}^{3}$ in most of the study settlements. In remote settlements like Buguma and Emuoha, some of the metals were not detected at all. In some instances, short-term limits for the pollutants exceeded WHO standards. The need for stakeholders in the region to articulate initiatives that support quality environmental practices was emphasized as laws pertaining to air quality regulations which are weak and less enforceable.

\section{Keywords}

Niger Delta, Regional Air Quality, Emissions from Petroleum

\section{Introduction}

The Niger Delta is the southernmost part of Nigeria where all the petroleum exploration and production takes

${ }^{*}$ Corresponding author. 
place and the generated income used to service at least $80 \%$ of the national budget. The implication is that industries are attracted to the region because of the presence of cheap and easy access to oil and gas. The spin-off is a region whose economy is always booming irrespective of situations elsewhere in the country. Unlike some parts of the world where there are cogent debates on energy options to optimize environmental sustainability, the Nigerian state is preoccupied with how to harness its petroleum endowment adequately to fund infrastructure and other aspirations of its teeming population. Nigeria is a member of the non-Annex 1 countries with no clear-cut limit on how much greenhouse gas it can emit, according to the Kyoto Protocol; this further promotes a negative emissions profile. The continuous flaring of associated gas known for the emission of all major air contaminants for instance; due to lax national regulations have caused Nigeria to be reputed as one of the highest. Globally, the volume of gas flared between 1996 and 2006 (during which time awareness of the detrimental impact of flare emissions on the global climate grew) remained relatively constant, ranging between 150 and 170 billion cubic meters (BCM). Nigeria's share of the total volume is approximately 24.1 BCM of gas; in comparison, the U.S. flares 2.8 BCM during the same time period [1] [2]. As a result of the associated activities with the exploration and production of oil and gas, the atmosphere of the Niger Delta is the primary sink into which the emissions are deposited. Rapid settlement and population growth in Nigeria as a whole and significant economic activities prompted by the huge petroleum industry in the Niger Delta are enough reasons to associate the area with diminished air quality. This widely acknowledged fact has led to series of studies and publications; most notable of which are the World Bank [3] study of the region and the Niger Delta Human Development Report by UNDP [4] that narrate paradoxes of poverty in the midst of plenty. The Environmental Assessment of Ogoniland by UNEP [5] delivered a catalogue of devastation due to oil pollution in Ogoniland, which was one of many ethnic Niger Delta settlements. These reports illustrate the level of pollution in the Niger Delta and in this paper the air quality of the area will be discussed in the context of the prevailing economic activities.

\section{Sources of Emissions That Impact the Regional Air Quality}

There are several sources of pollutants that affect the air quality of the Niger Delta region and some may be natural. The anaerobic condition of the Niger Delta swamps is ideal for the natural production of atmospheric contaminants like ammonia and methane and this has been documented in Funtua near Brass, Bayela State [6] and the swamps around Port Harcourt [7]. Anthropogenic sources include economic and industrial activities especially in large urban centres and industrial complexes; and the best known process that impact on the air quality of the region is the petroleum industry. An estimation of emissions using the emission factors from domestic sources in the Niger Delta which includes domestic lighting (using generators) and domestic cooking (using firewood and kerosene) constituted sources of significant emission of pollutants as the estimates show $70 \mathrm{kt} / \mathrm{year}$ of $\mathrm{CO} ; 50 \mathrm{kt} /$ year of $\mathrm{NO}_{\mathrm{x}} ; 3 \mathrm{kt} /$ year of $\mathrm{PM}_{10} ; 2.4 \mathrm{kt} /$ year of $\mathrm{SO}_{2} ; 60 \mathrm{t} /$ year of $\mathrm{VOC} ; 5.7 \mathrm{mt} /$ year of $\mathrm{CO}_{2}$ and 2 $\mathrm{kt} /$ year of $\mathrm{CH}_{4}$ released from domestic emissions [8]. A profile of gaseous emissions admitted to by one of the oil companies in Table 1 is illustrative. The sources of air pollutants from petroleum production include crude oil and condensate spills, gas flares, and vapours from storage, processing and transportation facilities.

There are over 14 public power plants in operation or under construction located in Afam I and II, Eleme, Port Harcourt, Sapele, Ughelli, Kwale, Gbaran, Aba, Omoku, Ikot Abasi, Odukpani, Alaoji and Azura-Edo. Many oil companies and heavy industries use private gas turbines to power their production facilities and residential quarters; for instance, the petrochemical plant in Eleme has four gas turbines and the liquefied natural gas complex in Bonny has ten gas turbines. Several new power plants are proposed in the near future, although these plants utilize natural gas regarded as relatively clean, they nevertheless emit noxious gases. The petroleumbased industries in the region include three refineries, two petrochemical plants and a 6-train gas liquefaction plant [11] that are still expanding, just as another fertilizer plant is under construction in Eleme by Idorama.

The heavy industries are notably the Aladja steel complex, the Ikot Abasi aluminium smelting company, and the Onne fertilizer plant. Typical sources of air pollutants in the Niger Delta are categorized in Table 2.

The Nigerian oil economy has fuelled the growth of cities in the Niger Delta. The most prominent of these cities is Port Harcourt, but there are others like Warri, Bonny, Eket and Omoku whose growth and recent sprawl are decidedly consequent upon the regional oil boom. In a spatially constrained island city like Bonny where large petroleum based liquefied gas plant and crude oil export terminal have led to severe urban congestion, the environment and air quality is invariably undermined [13]. Metropolises such as Port Harcourt are important for the large number of vehicle traffic and industries emissions. A myriad of human activities like construction sites, machine operation and maintenance also release emissions that impact air quality. Owning a power generating 
Table 1. Gas emissions in SPDC (Shell Nigeria) operations (000 tons).

\begin{tabular}{ccccccc}
\hline Pollutant & 1999 & 2000 & 2001 & 2002 & 2003 & 2004 \\
\hline $\mathrm{CO}_{2}$ & 18.10 & 21,838 & 22,489 & 15,467 & 18,798 & 19,798 \\
$\mathrm{CH}_{4}$ & 86.5 & 98.4 & 111.6 & 72.8 & 87.0 & 90.7 \\
VOCs & 135.3 & 160.2 & 183.3 & 100.4 & 117.2 & 122.2 \\
Gas flared & 6458 & 7693 & 7909 & 5222 & 6385 & 6611 \\
$\mathrm{SO}_{\mathrm{x}}$ & 1.5 & 1.7 & 1.8 & 1.1 & 1.1 & 1.1 \\
$\mathrm{NO}_{\mathrm{x}}$ & 20.1 & 17.8 & 27.3 & 22.3 & 23.1 & 21.9 \\
$\mathrm{HCFC} / \mathrm{CFC}$ & 2650 & 3459 & 1901 & 2960 & 1198 & 2403 \\
\hline
\end{tabular}

Source: [9] [10].

Table 2. Emission sources from human activities in the Niger Delta.

\begin{tabular}{|c|c|c|c|}
\hline Category & Emission Source & Nature of Pollutant & Impact \\
\hline Petroleum & $\begin{array}{l}\text { a) Gas flaring } \\
\text { b) Oil spill vapour } \\
\text { c) Venting } \\
\text { d) Fugitives }\end{array}$ & $\begin{array}{l}\text { Heat radiation noxious emissions, } \\
\text { Hazardous air pollutants (HAPs) }\end{array}$ & $\begin{array}{l}\text { Thermal conduction, air } \\
\text { pollution, noise, air pollution }\end{array}$ \\
\hline Heavy industries & $\begin{array}{l}\text { a) Cooling towers } \\
\text { b) Separators } \\
\text { c) Boilers } \\
\text { d) Burners } \\
\text { e) Venting }\end{array}$ & $\begin{array}{l}\text { HC \& VOC vapours HAPs, acid } \\
\text { precursors, flue gas, particulates }\end{array}$ & $\begin{array}{l}\text { Air pollution, vibration, acid } \\
\text { rain }\end{array}$ \\
\hline Other industries & $\begin{array}{l}\text { a) Foundries } \\
\text { b) Solvents } \\
\text { c) Vapours } \\
\text { d) Fuels } \\
\text { e) Feedstock }\end{array}$ & Noxious gases, HAPs & $\begin{array}{l}\text { Odour, health effects like } \\
\text { carcinogenic }\end{array}$ \\
\hline Power plants & $\begin{array}{l}\text { Over six gas fired thermal plants } \\
\text { exist. }\end{array}$ & $\mathrm{HC}$, noxious gases, $\mathrm{CO}_{2}$, particulates & $\begin{array}{l}\text { Greenhouse-gas, air } \\
\text { pollution }\end{array}$ \\
\hline $\begin{array}{l}\text { Automobiles, marine } \\
\text { vessels and machines }\end{array}$ & $\begin{array}{l}\text { a) Exhausts } \\
\text { b) Leaks } \\
\text { c) Wearing of tyres breaks, etc. }\end{array}$ & $\begin{array}{l}\mathrm{HC} \text {, noxious gases, } \mathrm{CO}_{2} \text {, particulates, } \\
\text { PAHs }\end{array}$ & $\begin{array}{l}\text { Bodily irritation, smoke, } \\
\text { noise }\end{array}$ \\
\hline Other activities & $\begin{array}{l}\text { a) Construction } \\
\text { b) Agriculture } \\
\text { c) Domestic sources }\end{array}$ & $\begin{array}{l}\text { Methane, dust and particulates, } \\
\text { noxious gases, etc. }\end{array}$ & Visibility, dust, etc. \\
\hline
\end{tabular}

Source: [12].

set has become a necessity in both the rural and urban areas of the region because public power supply in Nigeria is grossly unreliable [14]. As a result, all the major oil producing companies have undertaken to generate their operational power needs independently, through gas turbines. These generating sets are key sources of emissions into the atmosphere.

We have briefly overviewed the sources of emissions that impact on the air quality of the region. The location of a specific activity-form is likely to be associated with the potential air quality of its immediate vicinity and even beyond [15] [16]. The presence of heavy industries raises the level of atmospheric contamination in the region; likewise the sprawling urban centres and traffic congestion.

The air quality of an environment is tied to the atmospheric processes of the location. The air over the Niger Delta in terms of the weather systems does attenuate and sometimes enhance emissions dispersion; how they interact is noteworthy. Modelling of emissions to determine pollution transport in the region have been conducted by [15]-[17]. Small scale rural vocations such as bush burning as part of preparations for farming and the cottage processing of farm produce like oil palm also generate significant emissions [18]. 


\section{Methodology}

There is no systematic attempt to evaluate the air quality of any settlement in the Niger Delta region over prolonged period. The region is host to many industries and rapidly growing cities, capable of impinging on good air quality. Records of air quality data in the region are sourced mainly through discrete efforts for impact assessment of facilities aimed at implementing various regulations on the environment. The greatest drawback of existing information in characterizing the regional air quality of Nigeria's delta region is that they are not continuous. A good regional air quality record should be based on a network of permanent stations with monitoring schedule. Moreover, reference to data generated to meet regulatory requirements may underplay actual levels of emissions present in the atmosphere because the polluter who generated the data intends to portray a seeming clean bill of health.

During impact assessment, control measurements are taken to demonstrate how projects' location air quality differs from the general atmosphere. These controls can be assumed to reflect background air quality status of the region, except as already stated, they are not continuous over a significant period. It is from such records that this appraisal of air quality in the Niger Delta is based; therefore, data included here are not tied to any particular emission point nor are diurnal and seasonal variations captured. Although available records may be short on time, they are robust in the number of pollutants included. It has become quite routine for studies to include the primary pollutants like carbon monoxide $(\mathrm{CO})$, oxides of nitrogen $\left(\mathrm{NO}_{\mathrm{x}}\right)$, sulphur compounds $\left(\mathrm{SO}_{\mathrm{x}}\right)$, lead and suspended particulates; sometimes too heavy metals and hydrocarbon species, such as the BTEX (benzene, toluene, ethylene and xylene) are also monitored. A few researchers are also linking air quality measurements to meteorological conditions and atmospheric modelling of emissions. The settlements in this report are based on the criteria of data accessibility to the author, although, these settlements were not the primary objective for generating the data. The data pertain to the settlements only in the sense that control measurements were extrapolated for them. The settlements included in this report are Ahoada, Bonny, Brass, Buguma, Ukwugba, Eket, Nchia, Emuoha, Mbiama, Odukpani, Omoku, Owasa, Port Harcourt, Sapele, Ughelli and Warri. These settlements straddle six states in the region as well as the ecological and climatological sub-divisions of the Niger Delta, whose population estimated in the census of 2006 by NPC [19] was over 21 million.

The pollutants are grouped into three: the first category is mainly the primary pollutants emitted by industrial plants, automobiles and combustion processes. The emissions are carbon monoxide $(\mathrm{CO})$ nitrogen dioxide $\left(\mathrm{NO}_{2}\right)$, sulphur dioxide $\left(\mathrm{SO}_{2}\right)$, total hydrocarbons $(\mathrm{HC})$ and suspended particulate matter (SPM). Carbon dioxide $\left(\mathrm{CO}_{2}\right)$, a natural constituent of the atmosphere and a non-pollutant, but a greenhouse-gas is also included because of its growing profile in current environmental discourse. Carbon dioxide is not necessarily an air pollutant because it does not undergo secondary reactions, except as weak carbonic acid when mixed with moisture in the atmosphere. As a greenhouse gas, $\mathrm{CO}_{2}$ is important along with methane $\left(\mathrm{CH}_{4}\right)$ and chlorofluorocarbons, which is why it is included in the list of common air pollutants in this instance.

The second category are the hydrocarbon species particularly, the BTEX group. This category has the least number of measurement records. The third category comprises trace metals presence in the atmosphere of the region. Measurements presented in this report are compared to standards to ascertain whether they are within regulatory limits.

\section{Instrumentation for Data Measurement}

The data utilised in this study was sourced through secondary sources from impact assessment of facilities aimed at implementing air quality regulations on the environment and the various methods used are summarized in Table 3.

\section{Results and Discussion}

Results of measurement of emissions in the Niger Delta are summarised in Figure 1. Particulate load in the region's atmosphere ranged between $40 \mu \mathrm{g} / \mathrm{m}^{3}$ in Brass to $98 \mu \mathrm{g} / \mathrm{m}^{3}$ in Port Harcourt. The range of values for particulates depends on the time of the day, season, intensity of human activities and proximity to emission sources. All the settlements with high SPM such as Owasa $\left(79 \mu \mathrm{g} / \mathrm{m}^{3}\right)$, Nchia $\left(75 \mu \mathrm{g} / \mathrm{m}^{3}\right)$ and Mbiama $\left(73 \mu \mathrm{g} / \mathrm{m}^{3}\right)$ are located on busy highways, heavy industrial plants, numerous oil fields and gas flare points, or where construction activities are in progress. In terms of surface hydrology of the delta, the settlements with the highest suspended particulates are located on dryer lands and are accessible by road as well. It was estimated that the flaring of gas 
Table 3. Summary of methods used to measure emissions.

\begin{tabular}{|c|c|}
\hline Parameter & Method \\
\hline Sulphur dioxide & $\begin{array}{l}\mathrm{TCM} / \text { Pararosaniline }-\mathrm{SO}_{2} \text { is absorbed from the air in a potassium tetrachloromecurate and formaldehyde in } \\
\text { the following amounts by controlling the flow rate of sample and reagents. A pararosaniline methyl sulphuric } \\
\text { acid dye is formed. The absorbance of the coloured solution is determined at about } 550 \mathrm{~nm} \text { in a } \\
\text { spectrophotometer. Concentrations in the range of }<25 \text { to } 1000 \mu \mathrm{g} / \mathrm{m}^{3} \text { can be measured by this method [20]. } \\
\text { This method requires relatively simple apparatus. It is essentially specific to } \mathrm{SO}_{2} \text { since all known interference } \\
\text { are minimised or eliminated, samples are relatively stable after collection. It has been used widely as a } \\
\text { reference method and is covered by an international standard [21]. }\end{array}$ \\
\hline Nitrogen dioxide & $\begin{array}{l}\text { This method is intended for the manual determination of } \mathrm{NO}_{2} \text { in the atmosphere in the concentration range of a } \\
\text { few to about } 9400 \mu \mathrm{g} / \mathrm{m}^{3}(5 \mathrm{ppm}) \text { for sampling periods of up to two hours and flow rate of up to } 0.6 / \mathrm{min} \text {. The } \\
\text { principle of this method involve reacting } \mathrm{NO}_{2} \text { with diazolizing-coupling reagents (Sulphanilic acid and } \mathrm{N}- \\
\text { (I-naphthyl)-ethylene diamine dihydrochloride) to produce a deeply coloured azo dye whose intensity is } \\
\text { measured spectrophotometrically. It is sensitive enough to detect low concentration of } \mathrm{NO}_{2} \text {. This method has } \\
\text { been used extensively in the United States and Europe, it has been tested by many workers and is highly } \\
\text { recommended [20] [22]. }\end{array}$ \\
\hline Carbon dioxide & $\begin{array}{l}\text { Colorimetric chemical sensors-This detects emissions at their permissible exposure limit after some minutes } \\
\text { of exposure. The sensors consist of disposable array of cross-responsive nanoporous pigments whose colours } \\
\text { are changed by diverse chemical interaction with analytes. } \mathrm{CO}_{2} \text { levels could range up to } 10,000 \text { ppm on the } \\
\text { detector. }\end{array}$ \\
\hline Carbon monoxide & $\begin{array}{l}\text { Non-dispersive infrared-Non-Dispersive Infra-Red (NDIR) detectors are the industry standard method of } \\
\text { measuring the concentration of carbon oxides. The constituent gas in a sample will absorb some infra-red at a } \\
\text { particular frequency. By shining an infra-red beam through a sample cell (containing CO), and measuring the } \\
\text { amount of infra-red absorbed by the sample at the necessary wavelength, a NDIR detector is able to measure } \\
\text { the volumetric concentration of CO in the sample. }\end{array}$ \\
\hline $\begin{array}{l}\text { Hydrocarbons (total } \\
\text { \& BTEX) }\end{array}$ & $\begin{array}{l}\text { An ultraviolet-visible spectrophotometer with automatic cell driver and spectrum design system equipped with } \\
\text { quartz cells was used. With the spectrophotometer, the amount of a known chemical substance (concentrations) } \\
\text { can be determined by measuring the intensity of light detected depending on the range of wavelength of light } \\
\text { source. }\end{array}$ \\
\hline $\begin{array}{l}\text { Suspended Particulate } \\
\text { Matter (SPM) }\end{array}$ & $\begin{array}{l}\text { Gravimetric (non-destructive)_-The sample is taken through continuous filtration of ambient air on glass fibre } \\
\text { filtering material with a capturing capacity more than } 99.5 \% \text { and flow rate of } 33-55 \mathrm{~cm} \cdot \mathrm{s}^{-1} \text {. The filter head is } \\
\text { turned with the open side down, at a distance of } 1.5-3.0 \mathrm{~m} \text { above the surface. The sampling time was for } 24 \\
\text { hours. The sampling frequencies correspond to the character of the sampling site locations. The amount of } \\
\text { sample captured on the filter (in } \mu \mathrm{g} \text { ) is determined gravimetrically as a difference between the weight of the } \\
\text { filter prior to and after the exposure. }\end{array}$ \\
\hline Heavy metals & $\begin{array}{l}\text { Atomic absorption spectroscopy (AAS) - This method is very reliable and simple to use as it can analyze over } \\
62 \text { elements through atomic identification and quantification. Metals absorb ultraviolent lights in their } \\
\text { elemental form when they are excited by heat and each metal has a characteristics wavelength that will be } \\
\text { absorbed. The AAS instrument looks for a particular metal by focusing a beam of UV light at a specific } \\
\text { wavelength through a flame and into a detector. }\end{array}$ \\
\hline
\end{tabular}

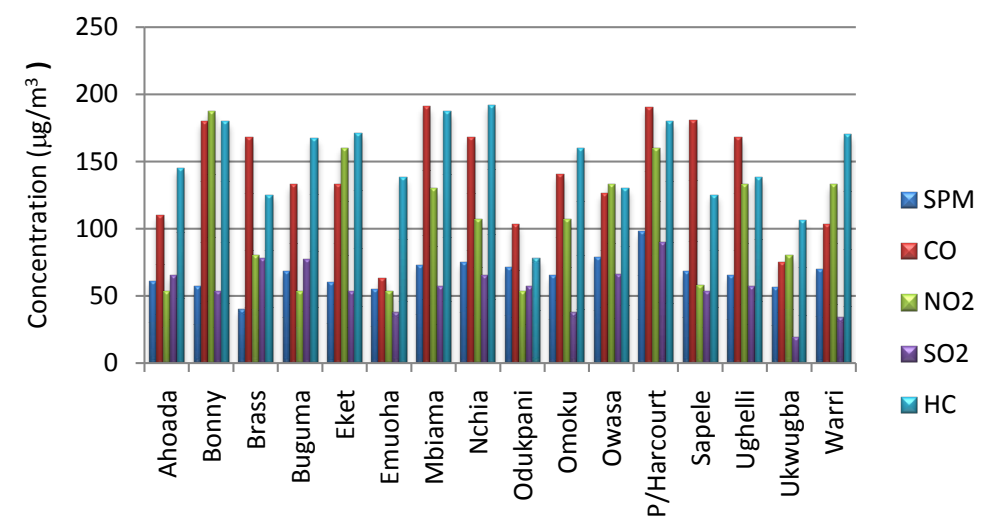

Location

Figure 1. Concentration of major air pollutants in the region. 
alone in the petroleum industry releases over 6000 tons of particulates into the atmosphere in the Niger Delta, annually [23].

[24] calculates that particulates from gas flares in Nigeria have a settling velocity of $1.15 \times 10^{8} \mathrm{~m} \cdot \mathrm{s}^{-1}$. This is indicative that fractions of the particles are aerosols which drift like atmospheric air molecules. The removal process is therefore through wet deposition instead of gravitational settling. The particles are captured by water droplets present in the atmosphere and are removed by a process called washout if insoluble. The main source for washout is impaction and interception, where a rain droplet removes particles in the layer below the cloud on its way down to the surface. If the particles are soluble they go into solution with rainwater. These observations are in line with [25] and Canada National Ambient Air Quality Objectives [26].

Most petroleum related flare facilities onshore in Nigeria are horizontal and point to a surface pit surrounded by a bund wall. The stack height is therefore zero. But due to buoyancy forces acting on the emission, the effective plume rise can be as much as $10 \mathrm{~m}$ [27]. With an effective stack height of $10 \mathrm{~m}$ the residence time is estimated at $8.70 \times 10^{8} \mathrm{~s}$ by [24]; thus, the possibility of these particles being carried to distant places by wind. Assuming a mean wind speed of $3 \mathrm{~m} \cdot \mathrm{s}^{-1}$, particulates from flares can be transported and dispersed at $2.61 \times 10^{6} \mathrm{~km}$ in the downwind direction. Therefore in one hour, pollutants will be transported $10.8 \mathrm{~km}$. This also supports calculations by [16] that pollutants are transported to distant areas far from their sources within the region.

Carbon monoxide concentrations were highest in Mbiama $\left(191 \mu \mathrm{g} / \mathrm{m}^{3}\right)$. Although Mbiama is a small town, it is however split into two halves by the busy East-West highway. Long distant trailer drivers use the small town as a stopover place; so at all times, there are heavy duty vehicles steaming on the roadside. Spot measurement of $\mathrm{CO}$ in Mbiama easily spike above $36,614 \mu \mathrm{g} / \mathrm{m}^{3}(20 \mathrm{ppm})$. This is a hazard to the periodic and daily markets that attract large number of traders from far flung areas of the Niger Delta. Emuohia, Ukwugba and Ahoada had the least concentration of $\mathrm{CO}$. All CO measurement in this study exceeded short-term limits and the reason may be due to the prevalence of too many smoking vehicles on Nigeria roads.

Nitrogen dioxide concentration was highest in Bonny $\left(187 \mu \mathrm{g} / \mathrm{m}^{3}\right)$. The least concentrations of $\mathrm{NO}_{2}$ were at Ahoada, Buguma and Odukpani $\left(53 \mu \mathrm{g} / \mathrm{m}^{3}\right)$. In Owasa, Ughelli and Warri the most important means of mobility is 2-stroke engine motorbikes, which is likely responsible for the $133 \mu \mathrm{g} / \mathrm{m}^{3}$ recorded. All sulphur dioxide measurements in this study were below short-term regulatory limits for 1 and $24 \mathrm{~h}$ for WHO (Table 4).

Sulphur dioxide is the criterion emission detected with the least concentrations in the regions atmosphere. It ranged between $19 \mu \mathrm{g} / \mathrm{m}^{3}$ in Ukwugba to $90 \mu \mathrm{g} / \mathrm{m}^{3}$ in Port Harcourt. Sulphur dioxide in the atmosphere arises from the combustion of fuels containing sulphur. Relatively, the petroleum obtained in Nigeria has negligible sulphur content; although a large part of the fuel supplied in the country are imported. Depending on the sources of such fuels, the sulphur content may be high. There are no publications on that, but the acrid smell of some imported fuels justifies the conclusion that their sulphur contents are higher than those produced in domestic refineries.

Total hydrocarbon in the atmosphere ranged from $78 \mu \mathrm{g} / \mathrm{m}^{3}$ in Odukpani to $192 \mu \mathrm{g} / \mathrm{m}^{3}$ in Nchia. The Niger Delta region as a whole is replete with petroleum production and processing facilities. There are many oil spill sites in the region and most waterways exhibit oil films on the surface. As much as $35 \%-65 \%$ of spill components can evaporate into the atmosphere within weeks [28] and this is possible with the predominantly light crudes of Niger Delta, under a perennially humid-hot climate. Settlements like Bonny and Nchia had high concentrations of hydrocarbon in the atmosphere because export terminals, petroleum refineries and liquefied natural gas processing facilities are present in them. The sources of hydrocarbon in the Niger Delta region are fairly ubiquitous. There are hundreds of petroleum production and processing facilities within a few miles of each other in the region from where hydrocarbons are vented. In addition, crude oil spills, incessant petroleum product pipeline breakage, associated gas flares, emissions from automobiles, power generators and machines are other sources of hydrocarbons in the region's atmosphere.

The most abundant of the BITEX group is benzene and toluene. Benzene ranged from $0.2-0.3 \mu \mathrm{g} / \mathrm{m}^{3}$ and it was present in all the locations. Toluene ranged from $0.1-0.5 \mu \mathrm{g} / \mathrm{m}^{3}$ and it was also present in all the locations monitored. Xylene was the next in abundance and it ranged between $0.1-0.2 \mu \mathrm{g} / \mathrm{m}^{3}$. Ethylene was detected only in one station at concentration of $0.1 \mu \mathrm{g} / \mathrm{m}^{3}$. It is justifiable to conclude that ethylene presence in the regional atmosphere is negligible. Their importance to air quality studies is that they are carcinogenic [32].

Carbon dioxide ranged between $400 \mathrm{ppm}$ Buguma to $450 \mathrm{ppm}$ in Port Harcourt. These values are similar to background concentrations of $\mathrm{CO}_{2}$ [33], although measurements taken near oil processing facilities like gas flares regularly rise above $450 \mathrm{ppm}$. Carbon compounds in the atmosphere are partly as a result of the burning of 
Table 4. Emissions tolerance limits and standards for ambient air quality.

\begin{tabular}{|c|c|c|c|c|}
\hline \multirow[b]{2}{*}{ Pollutants } & \multicolumn{2}{|c|}{ Nigeria (FMEV) } & \multirow{2}{*}{$\begin{array}{l}\text { National Air Quality } \\
\text { Standard for Nigeria }\end{array}$} & \multirow{2}{*}{$\begin{array}{c}\text { WHO Guidelines and World Bank } \\
\text { Standards }\end{array}$} \\
\hline & $\begin{array}{l}\text { Long-Term Tolerance } \\
\text { Limits } 24 \text { Hours }\left(\mathrm{mg} / \mathrm{m}^{3}\right)\end{array}$ & $\begin{array}{l}\text { Short-Term Tolerance } \\
\text { Limits } 30 \mathrm{~min}\left(\mathrm{mg} / \mathrm{m}^{3}\right)\end{array}$ & & \\
\hline $\begin{array}{l}\text { Suspended } \\
\text { particulate matter }\end{array}$ & 0.015 & 0.5 & $\begin{array}{c}250 \mu \mathrm{g} / \mathrm{m}^{3}(24 \mathrm{~h}) \\
600 \mu \mathrm{g} / \mathrm{m}^{3}(1 \mathrm{~h})\end{array}$ & $\begin{array}{c}60-90 \mu \mathrm{g} / \mathrm{m}^{3} \text { (annual mean) } \\
150-230 \mu \mathrm{g} / \mathrm{m}^{3}(24 \mathrm{~h})\end{array}$ \\
\hline Carbon dioxide & 10 vol. $\%$ & - & & - \\
\hline Carbon monoxide & 1.0 & 0.5 & $\begin{array}{l}10 \mu \mathrm{g} / \mathrm{m}^{3}(1 \mathrm{~h}) \\
20 \mu \mathrm{g} / \mathrm{m}^{3}(8 \mathrm{~h})\end{array}$ & $\begin{array}{c}60 \mu \mathrm{g} / \mathrm{m}^{3}(24 \mathrm{~h}), 10 \mu \mathrm{g} / \mathrm{m}^{3}(8 \mathrm{~h}) \\
30 \mu \mathrm{g} / \mathrm{m}^{3}(1 \mathrm{~h})\end{array}$ \\
\hline Nitrogen dioxide & 0.085 & 0.085 & $75-113 \mu \mathrm{g} / \mathrm{m}^{3}(24 \mathrm{~h})$ & $\begin{array}{c}40-50 \mu \mathrm{g} / \mathrm{m}^{3} \text { (annual), } 150(8 \mathrm{~h}) \\
200 \mu \mathrm{g} / \mathrm{m}^{3}(24 \mathrm{~h})\end{array}$ \\
\hline Sulphur dioxide & 0.05 & 0.5 & $\begin{array}{l}0.01(24 \mathrm{~h}) \\
0.1(1 \mathrm{~h})\end{array}$ & $\begin{array}{c}50 \mu \mathrm{g} / \mathrm{m}^{3} \text { annual, } 350 \mu \mathrm{g} / \mathrm{m}^{3}(1 \mathrm{~h}), \\
125 \mu \mathrm{g} / \mathrm{m}^{3}(24 \mathrm{~h})\end{array}$ \\
\hline Benzene & 0.8 & 0.2 & - & $1 \mu \mathrm{g} / \mathrm{m}^{3}$ \\
\hline Toluene & 0.6 & 0.6 & - & $1 \mathrm{mg} / \mathrm{m}^{3}$ (odour) $7.5 \mathrm{mg} / \mathrm{m}^{3}$ \\
\hline Ethylene & 5.0 & 5.0 & - & - \\
\hline Xylene & - & 0.2 & - & - \\
\hline $\begin{array}{l}\text { Hydrocarbon } \\
\quad \text { (total) }\end{array}$ & 2.0 & 5.0 & $160 \mu \mathrm{g} / \mathrm{m}^{3}(3 \mathrm{~h})$ & $160 \mu \mathrm{g} / \mathrm{m}^{3}$ \\
\hline Cadmium & 0.003 & 0.01 & - & $10-10 \mu \mathrm{g} / \mathrm{m}^{3}, 0.04 \mu \mathrm{g} / \mathrm{m}^{3}$ \\
\hline Chromium & 0.001 & 0.0015 & - & $1 \mu \mathrm{g} / \mathrm{m}^{3}$ \\
\hline Lead & 0.005 & 0.002 & - & $0.5-1 \mu \mathrm{g} / \mathrm{m}^{3}$ (annual) \\
\hline Manganese & 0.01 & 0.03 & - & $1 \mu \mathrm{g} / \mathrm{m}^{3}$ (annual) \\
\hline Vanadium & 0.002 & - & - & $1 \mu \mathrm{g} / \mathrm{m}^{3}(24 \mathrm{~h})$ \\
\hline
\end{tabular}

Sources: [29]-[31].

fossil fuel and the relevant compounds in this regard are carbon dioxide and carbon monoxide. Carbon dioxide rarely go into reaction in the atmosphere, its importance lies in the fact that it is one of the greenhouse gases, capable of increasing the overall heat balance of the earth. Since the turn of the century, background levels of carbon dioxide have increased to $400 \mathrm{ppm}$ [33].

Trace metals in the atmosphere are sometimes categorized as hazardous air pollutants (HAPs) along with volatile organic compounds (VOCs). Five metals were detected, namely; cadmium, chromium, lead, vanadium, zinc and manganese. Arsenic, barium, nickel and mercury were investigated but not detected. The most abundant of the metals was zinc, which was present at above $\left(2.0 \mu \mathrm{g} / \mathrm{m}^{3}\right)$ in all the settlements included in this study.

In remote settlements like Buguma and Emuoha some of the metals were not detected at all. Metals enter the atmosphere from several sources including the crust, automobile emissions (especially in the fuel and brake linings) and crude oil processing. Figure 2 shows trace metal measurements in the atmosphere of the region. Lead in the atmosphere of the region has been traced to its presence in some gasoline sold in Nigeria $(0.74 \mathrm{mg} / \mathrm{l})$, and described as one of the highest in the world by the [3]. Its accumulation in human tissues can affect mental function and may result in other health effects. The significant concentration of zinc in these areas of the Niger Delta may indicate the presence of trace metal pollution from oil exploration activities done in the flow stations close to study areas as well as cases of oil spills in the areas [34] [35]. [36] has reported the concentrations of trace metals in some oil producing locations from Brass and Bonny within the Niger Delta region. A study conducted by [37], show a significant levels of zinc in Port Harcourt $\left(22.91 \pm 6.26 \mu \mathrm{g} / \mathrm{m}^{3}\right)$ in the atmosphere. Industries which may be responsible for zinc concentration in the atmosphere in Port Harcourt include Pipeline Products and Marketing Company, PPMC at Eleme, Port Harcourt Refinery Company at Alasa, Eleme, Eleme Petrochemical Industry, etc. [38]. These industries together with regular petroleum exploration and exploitation activities may be responsible for the release of trace metals in the atmosphere which is being transported by meteorological factors from Port Harcourt to other part of the Niger Delta [37]. 


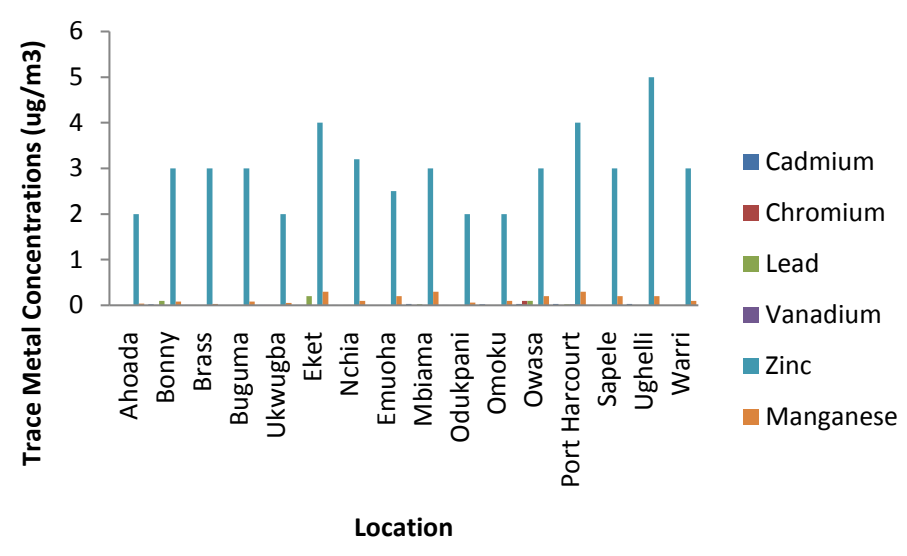

Figure 2. Concentration of trace metals in the region's atmosphere.

\section{Conclusion}

Laws on environment, as they pertain to air quality regulations, are presently very weak in Nigeria and existing environmental standards do not include specific provisions for all possible emission sources. Stakeholders at all level in the country have to articulate initiatives that support quality environmental practices. Specific air pollution and environmental standards ought to be more stringent targeting sources like factories, incineration and vehicle emissions. There should be air quality standards for designated areas based on the kind of activities that are prevalent. Standards easily degenerate into disputes if clear-cut protocols are not instituted to guide practice and enforcement on mutually agreeable methods. Pioneering the use of air quality modeling in Niger Delta as obtainable in some countries appears to be appropriate because it is a versatile instrument for regulatory controls. Traffic flow in large cities should be enhanced at all times because high mobility produces turbulence that aids dispersion, just as steaming automobiles in a traffic jam emit pollutants that can fumigate under certain weather conditions. There should be permanent air monitoring stations all over the region to provide air quality alerts and spot places where activity changes should be prescribed in order to improve air quality.

\section{References}

[1] Elvidge, C.D., Baugh, K.E., Tuttle, B.T., Howard, A.T., Pack, D.W. and Erwin, E.H. (2007) A Twelve-Year Record of National and Global Gas Flaring Volumes Estimated Using Satellite Data. Final Report to the World Bank, 107 p.

[2] JINN (2010) Gas Flaring in Nigeria: An Overview. Justice in Nigeria Now. http://justiceinnigerianow.org/gas-flaring

[3] World Bank (1995) Defining an Environmental Development Strategy for the Niger Delta. Vol. 1, Industry and Energy Operations, West Central Africa Department.

[4] UNDP (2006) Niger Delta Human Development Report. United Nations Development Programme, Abuja, 299 p.

[5] UNEP (2011) Environmental Assessment of Ogoniland. United Nations Environmental Programme, Nairobi, 262 p.

[6] Initiates (1999) Gas Emission Study/Investigation at Fantuo Community. NAOC, Port Harcourt, 65 p.

[7] Obunwo, C.C., Ede, P.N. and Jegede, M. (2009) Estimation of Methane from Two Mangrove Habitats in Port Harcourt of the Niger Delta Area, Nigeria. International Journal of Chemistry, 1, 62-65.

[8] Fagbeja, M.A., Hill, J., Chatterton, T., Longhurst, J. and Akinyede, J. (2013) Residential-Source Emission Inventory for the Niger Delta-A Methodological Approach. Journal of Sustainable Development, 6, 98-120. http://dx.doi.org/10.5539/jsd.v6n6p98

[9] SPDC (2004) 2003 People and Environment Annual Report. 45 p.

[10] SPDC (2005) 2004 People and Environment Annual Report. 33 p.

[11] NLNG (2002) Nigeria LNG Plant Overview. Training Department, Bonny.

[12] Ede, P.N. (1998) Pollution and the Rivers State Environment. Nigerian Research Review, 1, 81-89.

[13] Ede, P.N., Edokpa, D. and Israel-Cookey, C. (2011) The Relative Contribution of an LNG Plant Emission to the Regional Air Quality of Nigeria. Journal of the Nigerian Society of Chemical Engineers, 26, 1-11.

[14] Ede, P.N. and Oriji, I.B. (2013) Emissions from Private Power Generating Equipment in Port Harcourt, Nigeria. Nature and Science, 11, 59-64. 
[15] Sonibare, J.A. and Ede, P.N. (2009) Potential Impacts of Integrated Oil and Gas Plant on Ambient Air Quality. Energy and Environment, 20, 331-345. http://dx.doi.org/10.1260/095830509788066394

[16] Ede, P.N., Edokpa, D.O. and Ayodeji, O. (2011) Aspects of Air Quality Status of Bonny Island, Nigeria Attributed to an LNG Plant. Energy \& Environment, 22, 891-909. http://dx.doi.org/10.1260/0958-305X.22.7.891

[17] Edokpa, D.O. and Ede, P.N. (2013) Challenge of Associated Gas Flaring and Emissions Propagation in Nigeria. Academia Arena, 5, 28-35.

[18] Ede, P.N., Obunwa, C.C. and Nlerumchi, S.C. (2010) Air Quality Studies around Some Local Palm Oil Mill Plant at the Northern Fringes of the Niger Delta Area, Nigeria. Journal of Chemical Society of Nigeria, 35, 6-10.

[19] NPC (2007) Legal Notice on Publication of 2006 Census Report. National Population Commission, Lagos.

[20] WHO (1976) Selected Methods of Measuring Air Pollutants. WHO Offset Publication No. 24, E, Geneva.

[21] ISO 6767 (1990) Ambient Air Determination of the Mass Determination of Sulphur Dioxide Tetrachloromercurate (TCM)/Pararosaniline Method.

[22] ISO 6768 (1985) Ambient Air Determination of the Mass Concentration of Nitrogen Dioxide Modified Griess Saltzman Method.

[23] Ede, P.N., Seiba, I.H. and Igwe, F.U. (2006) Combustion Efficiency Determined for Selected Flare Points in the Niger Delta Area. African Journal of Environmental Pollution and Health, 5, 19-25.

[24] Seiba, I.H. (2006) The Production and Removal from the Air of Particulates in Associated Gas Flares in Nigeria. Unpublished Master's Thesis, Institute of Geosciences and Space Technology, Rivers State University of Science and Technology, Port Harcourt, $121 \mathrm{p}$.

[25] Guttorp, P. (1986) The Boundary Layer.

[26] Canada National Ambient Air Quality Objective for Particulate Matter (Executive Summary) (2003) Physical and Chemical Characteristics. http:/www.hesc.go.ca/hecssesc/airquality/publications/particulate/matter-exec-summa

[27] Ede, P.N. (1995) An Analysis of the Atmospheric Impact of Gas Flaring in Rivers State. Unpublished Master's Thesis, Department of Geography, University of Port Harcourt, Choba, $102 \mathrm{p}$.

[28] Asthana, D.K. and Asthana, M. (2003) Environment: Problems and Solutions. S. Chand \& Company, New Delhi, 434 p.

[29] Federal Ministry of Environment, FMEv (1991) Guidelines and Standards for Environment Pollution Control in Nigeria. FEPA, Lagos, $250 \mathrm{p}$.

[30] WHO (2006) WHO Air Quality Guidelines - Global Update 2005: Summary of Risk Assessment. The World Health Organisation, Geneva, $22 \mathrm{p}$.

[31] World Bank (1995) Initial Draft of Industrial Pollution Prevention and Abatement Handbook. World Bank, Environment Department, Washington DC.

[32] Khitoliya, R.K. (2004) Environmental Pollution Management and Control for Sustainable Development. S. Chand and Company, New Delhi, 309 p.

[33] IPCC (2014) Summary for Policymakers. In: Edenhofer, O., Pichs-Madruga, R., Sokona, Y., Farahani, E., Kadner, S., Seyboth, K., et al., Eds., Climate Change 2014, Mitigation of Climate Change, Cambridge University Press, Cambridge, United Kingdom and New York, 9.

[34] Obi-Iyeke, G.E. (2014) Trace Metal Dynamics in Some Leafy Vegetables Consumed in Warri, Niger Delta Region of Nigeria. International Journal of Research and Reviews in Applied Sciences, 18, 279-284.

[35] Omofonmwan, S.I. and Odia, L.O. (2009) Oil Exploration and Conflict in the Niger Delta Region of Nigeria. Journal of Human Ecology, 26, 25-30.

[36] Nwadinigwe, C.A. and Nwaorgu, O.N. (1999) Metal Contaminants in Some Nigerian Well-Head Crudes: Comparative Analysis. Journal of the Chemical Society of Nigeria, 24, 118-121.

[37] Uno, U.A., Ekpo, B.O., Etuk, V.E., Etuk, H.S. and Ibok, U.J. (2013) Comparative Study of Levels of Trace Metals in Airborne Particulates in Some Cities of Niger Delta Region of Nigeria. Environmental and Pollution, 2, 110-121.

[38] Ekweozor, I.K.E., Dambo, W.B. and Daka, E.R. (2003) Zinc and Cadmium Levels in Crassostrea gasar from the Lower Bonny Estuary, Nigeria. Journal of Nigerian Environmental Society, 1, 31-40. 